\title{
Erratum
}

\section{Plasma fetuin-A levels are reduced in patients with hypothyroidism}

\section{Okan Bakiner, Emre Bozkirli, Derun Ertugrul' ${ }^{1}$, Nurzen Sezgin ${ }^{2}$ and Eda Ertorer}

Department of Endocrinology and Metabolism Diseases, Faculty of Medicine, Baskent University, Dadaloglu Mah. Serinevler 2591 Sk., No. 4/A, 01250 Yuregir/Adana, Turkey, 'Department of Internal Medicine, Kecioren Teaching and Research Hospital, Ankara, Turkey and ${ }^{2}$ Department of Biochemistry, Faculty of Medicine, Baskent University, Adana, Turkey
Correspondence

should be addressed

to O Bakiner

Email

okanbakiner@mynet.com

The authors apologise for an error in their article titled 'Plasma fetuin-A levels are reduced in patients with hypothyroidism' published in the European Journal of Endocrinology 2014, Vol 170 Iss 3, pp 411-418. The unit used for serum fetuin-A levels throughout the article was wrongly given as $\mathrm{ng} / \mathrm{ml}$. The correct unit used should have been $\mu \mathrm{g} / \mathrm{ml}$. 